This is a post-print (Version 2) of the article, which was originally published in International Journal of Cultural Studies. 2015. Vol. 18(6) 645-660 by SAGE Publications Ltd. The publishers version of this article is available at http://dx.doi.org/ 10.1177/1367877913515870

Suggested citation:

Stanković, Peter. 2015. Rustic obsessions: The role of Slovenian folk pop in the Slovenian national imaginary. International Journal of Cultural Studies 18 (6):645-660. doi: 10.1177/1367877913515870

Peter Stanković:

\title{
Rustic obsessions: The role of Slovenian folk pop in the Slovenian national imaginary
}




\section{Introduction}

Slovenia is a country with a turbulent history. Many older Slovenians, for example, can say that they have lived in no fewer than seven different countries during their lifetimes without ever moving to a different place. It is also important that the historical experiences of people living in Slovenian regions are very diverse, as are their respective cultures. This probably sounds rather unusual if we take into account the fact that Slovenia is a small country, with no more than 2 million inhabitants, but Slovenian regions have in the past belonged to different empires or states and have consequently developed in very disparate contexts. The Slovenian nationalist movement, which began in the $19^{\text {th }}$ century, managed to join all these regions into a single federal unit only in 1918 (Slovenia as part of the Kingdom of Serbs, Croats, and Slovenians, which later became Yugoslavia). In 1991, Slovenia proclaimed independence from Yugoslavia and became a sovereign state, yet the problem of its cultural diversity remains: if nothing else, Slovenian national identity is relatively unstable and is to a large extent limited to a handful of official narratives and popular impressions.

Among the most prominent narratives that unite different Slovenian histories and experiences in a coherent whole is the one about Slovenian literati who have helped to establish the Slovenian language standard as equal to other European languages. This is one of the first things that children learn in school and there are also several public holidays that commemorate these authors. Yet, given the inherent instability of Slovenian national identity, the official narratives are obviously not enough to produce consistent identifications with the abstract and rather new concept of 'Slovenianess' [there were not many individuals that would identify themselves as Slovenians before the second half of the 19th century (Vodopivec, 2006: 46)]. It could be argued, therefore, that there are also other factors that help to produce contemporary Slovenian national identity. Given that we live in media-saturated societies, it would seem obvious that among these is also popular culture. The few works that touch upon the issue (e. g. Štefančič, 2005; Stanković, 2012) clearly suggest, for example, that Slovenian film has contributed substantially to the popular understandings of what 'Slovenianess' actually is. But what about other segments of popular culture?

In the article I will address the relationship between the processes of Slovenian national identity construction and Slovenian popular music. After all, there is plenty of evidence that music plays a significant role in national identity construction (e.g. Scrugg, 1999; Sultanova, 2005; Degirmenci, 2006).

Bohlman (2004: 12) argues, for example, that

'music is malleable in the service of the nation not because it is a product of national and nationalist ideologies but rather because musics of all forms and genres can articulate the processes that shape the state. Music can narrate national myths and transform them into nationalist histories.'

Baily (1994: 48), in his turn, points out that music's special effectiveness in this respect is that - beyond the ability to identify different ethnic and social groups - it has potent emotional connotations that 'can be used to assert and negotiate identity in a particularly powerful way'. Another important point in this respect is made by Stokes, who argues that music also serves to negotiate and transform various hierarchies of place.

'The case of private collection of records, tapes, and CDs illustrates the ways in which music can be used as a means of transcending the limitations of our own place in the world, of constructing trajectories rather than boundaries across space.' (1994: 4)

Unfortunately, there has not been much written about these issues in the case of Slovenia, so I will have to begin more or less from scratch. The topic is also complex [it ranges from the possible characteristics of texts themselves to audience reception], which means that I will not be able to address all of its aspects. I will focus, therefore, on just one of its dimensions and will only later on try to infer possible implications for the analysis of the relationship between the construction of a Slovenian national identity and Slovenian popular music as a whole. The dimension concerns the question of how Slovenians perceive Slovenian popular music as expressing something that they identify as Slovenianess.

Because my point of departure is that national identities are not some natural or eternal substances but rather constructs produced by different discoursive operations, I am not interested here in which elements of Slovenian popular music are actually Slovenian. After all, from the constructivist point of view, there are no 
such essences (compare: Anderson, 1991, Gellner, 1983, Stokes, 1994: 6). What I aim to identify here is rather what the audiences themselves perceive as typically Slovenian in Slovenian popular music and, in the second part of the article, to relate these characteristics to the possible discoursive frameworks that integrate diverse Slovenian cultural experiences and cultural references into a consistent whole.

\section{Methodology}

In my effort to identify popular understandings of the relationship between Slovenian national identity and Slovenian popular music, I will use results of empirical research on Slovenian popular music audiences that we conducted for the Popular Music Heritage, Cultural Memory and Cultural Identity project by the HERA Joint Research Programme. The Slovenian part of the research was based on interviews with popular music audiences from four Slovenian regions. The interviews were conducted between 10 October 2011 and 30 May 2012. Different regions were targeted in order to identify possible variations between different parts of the country, given that these have rather disparate histories and cultures. The selected regions are the CentralSlovenian region around the capital city, Ljubljana; the Stajerska region, located in the northeastern part of the country and culturally and historically strongly related to the Steiermark region in Austria; the Primorska region, at the southern tip of the country and historically part of the Venetian republic; and Pomurje, economically the least developed region in the country, near the Hungarian border. The interviewees were found with the help of the snowball method: the interviewers usually start with people they know and ask them to help them establish further contacts. The only thing that we actively looked for when trying to find people who would be willing to participate in the research was that they were of different age groups. The reason for this is a strong possibility that different generations in Slovenia understand Slovenianess and its relationship to Slovenian popular music differently.

In all, 150 interviews were conducted; 51 of these were done with people from the Central-Slovenian region, 47 from Štajerska, 28 from Primorska, and 10 from Pomurje. The other cases turned out to be first- or second-generation immigrants from other former Yugoslavian republics; because of their different cultural backgrounds, which probably relate them to the other former Yugoslavian republics (now independent states) rather than Slovenian regions that they live in at the moment, we wanted to keep them separate. The number of interviewees is rather uneven by region, but this reflects the respective sizes of these regions and our limited networks in some of these (above all in the smallest region in this group, Pomurje). But, because we did not aim at statistically significant results of the research, this probably should not be a problem. As mentioned, we also divided the interviewees into different categories according to their age. Of all interviewees, 25 were born in 1951 or earlier, 78 were born between 1952 and 1980, and 47 were born in 1981 or later. The age groups are constructed in such a way that they form three basic generations: the old, the middle-aged, and the young.

The interviews covered several different topics about the listening habits of the interviewees. For the purposes of the present article, I focused primarily on the answers to questions about the audiences' understanding of Slovenian popular music as it relates to the Slovenian national identity. Most important in this respect were two questions. The first one asked which Slovenian popular music acts or styles could be understood as typically Slovenian, and the second one asked what are possible defining characteristics of these acts or styles. What I wanted to identify here is not only which Slovenian popular music styles are understood by the audiences as expressing some kind of Slovenian essence but also which elements of the vast plurality of possible signifiers of Slovenianess are actually recognised as such in practice. In order to obtain a more comprehensive picture I have also made some references to the interviewees' responses to the set of questions about their personal memories related to popular music. These questions were: which is your earliest popular music related memory; which are the places/sites that are related to your most favourite popular music memory; which popular music styles or acts were your favourites when you were young; what kind of emotions do these styles or acts trigger in you today; and are there any styles or acts that you did not like when you were young but that you like now? 


\section{The sounds of Slovenia?}

The data that we received from the research is complex. It comprises 150 interviews that cover four Slovenian regions and immigrants from the former Yugoslavian republics, as well as three different age groups. Therefore, it might be useful to begin with an overview of the most important results in a single comprehensive table (Table 1). For reasons of convenience, the results presented are for the time being limited to the answers to the first question, namely which Slovenian popular music acts or genres could be understood as typically Slovenian. Here, the interviewees have been also asked to state if they personally like the music style that they identify as somehow typically Slovenian, so the answers to this sub-question are presented as well, although in a rather rough manner: the reason for this is that they did not necessarily answer to the sub-question in a straightforward manner (or at all).

\begin{tabular}{|c|c|c|c|}
\hline Region & Age group & n & Music styles identified as typically Slovenian \\
\hline \multirow[t]{3}{*}{$\begin{array}{l}\text { Central } \\
\text { Slovenian }\end{array}$} & 1951 or older & 11 & $\begin{array}{l}9 \text { folk pop; } 1 \text { contemporary folk music; } 1 \text { Yu rock and classical. Most of them like folk pop very } \\
\text { much. }\end{array}$ \\
\hline & 1951-1981 & 22 & $\begin{array}{l}1 \text { Yu rock; all others (21) folk pop, of which } 3 \text { cases folk pop and Laibach, } 2 \text { cases folk pop and } \\
\text { Slovenian pop music, and } 1 \text { case folk pop and folk rock singers. Approximately one half of the } \\
\text { interviewees also like folk pop. }\end{array}$ \\
\hline & 1981 or younger & 18 & $\begin{array}{l}2 \text { pop; all others (16) folk pop, } 2 \text { of these folk pop and rock. Approximately one half of the } \\
\text { interviewees also listen to folk pop, although some confess that they actually 'do not do so very } \\
\text { often'. }\end{array}$ \\
\hline \multirow[t]{3}{*}{ Primorska } & 1951 or older & 3 & All (3) folk pop. They also like it very much. \\
\hline & 1951-1981 & 15 & $\begin{array}{l}12 \text { folk pop, } 1 \text { folk pop and pop songs that have been 'appropriated by the people'; } 1 \text { rock; } 1 \\
\text { statement that there is 'no such thing as typical Slovenian music'. Some like folk pop, some don't. }\end{array}$ \\
\hline & 1981 or younger & 10 & $\begin{array}{l}\text { All (10) folk pop, of which } 1 \text { folk pop and slovenska popevka, rock, and punk. For the most part, } \\
\text { they do not listen to folk pop or they do so only on 'special occasions' (parties, fetes). }\end{array}$ \\
\hline \multirow[t]{3}{*}{ Štajerska } & 1951 or older & 7 & All (7) folk pop. They also like it. \\
\hline & 1951-1981 & 27 & $\begin{array}{l}18 \text { folk pop; } 2 \text { folk pop and rock (one gives example of Pankrti, the other of Laibach); } 4 \text { folk pop } \\
\text { and folk rock (e. g., Kreslin); } 1 \text { folk pop and turbo folk; } 1 \text { rock (Siddharta); } 1 \text { contemporary folk } \\
\text { music (e. g., Katalena, Terra folk). Some like folk pop, some don't, and there are also several } \\
\text { responses that say 'occasionally'. }\end{array}$ \\
\hline & 1981 or younger & 13 & All (13) folk pop. The majority do not like this style. \\
\hline \multirow[t]{3}{*}{ Pomurje } & 1951 or older & 3 & All (3) folk pop. They also like it very much. \\
\hline & 1951-1981 & 3 & All (3) folk pop. Mixed feelings about this music style. \\
\hline & 1981 or younger & 4 & 2 folk pop; 1 contemporary folk music; 1 turbo folk. Some like folk pop, some don’t. \\
\hline \multirow[t]{3}{*}{ Immigrants } & -1951 & 1 & 1 Dalmatian songs. \\
\hline & $1951-1981$ & 9 & $\begin{array}{l}\text { All (9) state that typical Slovenian music is folk pop. They do not like it, though. As for the music } \\
\text { of their own countries they cite music styles such as Yu rock, starogradske, sevdalinke, traditional } \\
\text { music etc. They like these styles. }\end{array}$ \\
\hline & 1981 or younger & 4 & $\begin{array}{l}\text { For all (14) typically Slovenian music is folk pop, which they do not like. As for the music of } \\
\text { their own respective countries of origin (all ex-Yugoslavia), they point out different music styles, } \\
\text { emphasising that these typically cover topics related to love, e.g., longing, betrayal, and the like. } \\
\text { They like this music, but only 'to an extent'. }\end{array}$ \\
\hline
\end{tabular}

\section{Table 1.}

When planning the research, we did not aim at a statistically significant sample, so the numbers presented have limited explanatory potential. The table also shows that the answers were quite complex, which means that it is difficult to translate them into simple or clear-cut categories, let alone to draw decisive conclusions from the frequencies alone. The focus of my analysis will therefore be to analyse the discoursive frameworks employed by the interviewees when discussing something that they perceive as typical Slovenian popular music, but there are some very obvious trends discernible already on the level of tentative grouping of the results. One reason for this is that the answers are in several respects quite consistent, in spite of everything, and the other that the number of interviews conducted is quite substantial, so the trends could be understood as at least informative.

The most obvious thing to note on this level is that the vast majority of the interviewees identified just one music style or its most popular acts as expressing something that they recognise as typically Slovenian. The 
genre in question is Slovenian folk pop (narodno-zabavna glasba - literary 'entertaining folk music'). This genre is, at least according to the results, perceived as the unquestionable music signifier of Slovenianess, irrespective to the place of origin of the interviewees, their age or ethnicity. There were, for example, just a few immigrants that did not agree that folk pop is the Slovenian music. These few exceptions among the interviewees of immigrant descent suggested Yu rock instead (rock music made in former Yugoslavian republics until the dissolution of the country in 1991) in 2 cases; Slovenian pop music in 1 case; classical music in 1 case; turbo folk in 1 case; and contemporary folk music in 3 cases. But all these figures are very small. A slightly greater number of interviewees stated that typically Slovenian music is Slovenian folk pop and something else. More precisely, 4 interviewees mention folk pop and Laibach (internationally renowned Slovenian industrial rock band); 4 interviewees folk pop and rock music (the most frequently referenced example is post-rock group Siddharta); 2 interviewees folk pop and Slovenian pop; 1 interviewee folk pop and Slovenska popevka (an unique mixture of pop rock and French chanson promoted by the socialist government in the 1960s as a more 'civilised' alternative to the incoming Beatlemania); 1 interviewee folk pop and contemporary pop; 5 interviewees folk pop and folk rock; 3 interviewees folk pop and Pankrti (an influential punk rock group); 1 interviewee folk pop and the pop songs that have been 'appropriated by the people' and are now part of the popular canon (to be sung on various occasions; e.g., songs by Andrej Šifrer); and 1 interviewee folk pop and turbo folk (a mix of dance and folk pop).

There is a notable consistency also in respect to the sub-question about the personal liking of the music style identified as the most typically Slovenian, at least according to generations. Namely, the older generation almost uniformly likes the genre of folk pop; the middle generation seems to be divided among those who are profoundly attached to folk pop and those who express explicit annoyance with it (there seems so be roughly the same proportion of both, with several interviewees in between or not declaring their feelings about this music style); while the younger generation also seems to be divided between folk pop lovers and folk pop haters, although not so decisively as the middle-aged generation. Here, it appears that there are not many that would be totally opposed to folk pop, even if they do not listen to it, while on the other the majority of those who express their liking of folk pop, admits that they actually 'do not listen to it very often'.

If there seems to be a strong intra-generational consensus about the centrality of Slovenian folk pop in Slovenian symbolic universe, with differences only in respect to the personal attachment to this music style, there are virtually no differences discernible among the interviewees from different regions. At least according to the result, the opinions of interviewees are virtually the same in all four targeted Slovenian regions. A special case in this respect are the immigrants from the other former Yugoslavian republics. Almost all interviewees who are the first- or second-generation immigrants also recognise Slovenian folk pop as somehow the most Slovenian music style of all, but at the same time they very uniformly and explicitly state that they themselves do not like it at all.

Let us now move on to the qualitative analysis. Beginning with the question about which Slovenian popular music acts or genres could be understood as typically Slovenian, we have already pointed out that the majority of interviewees stated that there is essentially just one music style that is typically Slovenian, folk pop. The majority has also provided a few examples (most frequently Avseniki, Ansambel Lojzeta Slaka, and Modrijani: all these are prominent acts on the Slovenian folk pop scene), but how did the interviewees explain their choices? What is in this music that makes it 'Slovenian' at all?

The answers and explanations provided by the interviewees are diverse. Predictably, there are many simple answers with no explanations. As such, these are not very useful for the analysis except for significant point that they obviously take the 'Slovenianess' of Slovenian folk pop as a given fact. Here are some quotes that could illustrate the point.

'This is according to my opinion primarily folk pop. Yes, I like it a lot' (Central-Slovenian region, middle-aged).

'Of course there are musicians that are typical for Slovenia. Among them are Slak, Avsenik, and Modrijani. I like this music as it is symbol of our state'. (Štajerska, middle-aged).

I think that the majority of our folk pop music acts represent music that is typically Slovenian. I would like to point out Slavko Avsenik, who is among my favourites' (Central-Slovenian region, older). 
Yet there are also more thorough accounts. Among them are answers that complain about the low esteem enjoyed by folk pop music.

'There is one music style that is recognisably Slovenian. This is Slovenian folk pop, which used to be ridiculed by the young, but this music is part of us, we identify ourselves with it, it is part of our heritage and tradition' (Štajerska, older).

'Typical for our country is folk pop music. It used to be repressed, but now it comes to the fore again' (CentralSlovenian region, older).

More prominently, several interviewees stressed that it is good for Slovenia to have its own music identity. This, of course, does not explain why it is precisely Slovenian folk pop that expresses this identity, but the answers are significant as they point to a certain traditionalistic evaluative disposition in the sense that it is not important what it is just as long as it is ours. Notably, this view is also expressed by several respondents, who personally do not like or listen to folk pop.

'Avsenik brothers rule and I think it is great that we [Slovenians] have our own tradition and music. It is also good that there are many new folk pop bands emerging with young musicians! I do not like this kind of music, though.' (CentralSlovenian, middle-aged)

'Personally, I don't like folk pop, but I do respect the fact that we have several good, legendary acts in this genre, even world-famous.' (Central-Slovenian region, middle-aged)

'I don’t like the music, but I like the national identity promoted by folk-pop' (Štajerska, middle-aged)

However, at least some interviewees expressed a degree of hesitation in respect to the authenticity of Slovenian folk pop. For the most part, these people do point out Slovenian folk pop as probably the most typically Slovenian music, but they wonder whether it is actually authentically or exclusively Slovenian.

'I wouldn't like to limit the answer to our country alone. There is a wider geographical region that includes different countries, Austria, Slovenia, and Switzerland, for example. There is a genre that is characteristic for this whole region, we Slovenians call it "beef music" [a derogatory popular term for folk pop] or yodelling' (laughs). (Central-Slovenian region, younger)

'I think that this could be Alpine music. But this music is quite similar to the German music of this kind, except for the rhythms that are slightly different.' (Štajerska, middle-aged)

Yet actually there were not many that would question the 'Slovenianess' of Slovenian folk pop. In all, there were just 3 interviewees that did so. Much greater is the number of those who resolutely emphasise that the uniqueness of Slovenian folk pop reflects the unique Slovenian historical and cultural experiences.

'Of course there are music styles that are characteristic for different countries: they reflect their developments and histories. In Slovenia, for example, Slovenian folk pop is the most characteristic.' (Štajerska, older)

'Just as there are different cultures there are also different music styles. For Germans, for example, as well as for the northern countries in general, one could say that metal music is most typical. In Slovenia, it is folk pop." (Primorska, younger)

That Slovenian folk pop stands as the hegemonic signifier of 'Slovenianess' in Slovenian popular music is shown also by the answers of the emigrants. Here, the respondents singled out Slovenian pop as the music style that represents Slovenia as well, yet they consistently emphasised that they do not like it. Given their experiences of symbolic degradation in Slovenia by the Slovenian ethnic majority, this is not surprising. But this detail is important nevertheless, because it clearly suggests that the emigrants' uneasiness in Slovenia is to a notable extent articulated precisely through their disliking of Slovenian folk pop.

'For Slovenia is typical "beef music", which I do not like, and Slovenian pop, which I do not like as well.' (Immigrant, middle-aged)

'Of course, my parents come from Republika Srbska and there you listen only to folk music, Balkan folk music, to be more precise [laughter]. As I have already mentioned, I like this kind of music: I am listening to it already for eight years or perhaps even more. Slovenian folk pop, however, is not like Balkan folk pop. I do not like Slovenian folk pop even if I was born here in Slovenia.' (Emigrant, younger) 
In the second question regarding the relationship between Slovenian popular music and national identity, we asked the interviewees to elaborate on their statement from the previous question. More precisely, we asked them what is typical in the selected music style and how could this be related to Slovenian national identity. Unfortunately, it seems that this question confused many interviewees, so for the most part they responded with just short descriptions. The majority simply responded with a few general characteristics of Slovenian folk pop.

'Folk costumes, accordion.' (Central-Slovenian region, middle-aged)

'Monotony and always the same rhythm.' (Štajerska, middle-aged)

'Accordion or a combination of accordion and clarinet. And nice songs. (Primorska, middle-aged)

But there were also more elaborate answers. Among them are arguments that tried to explain the supposed 'Slovenianess' of Slovenian folk pop in terms of their contribution to national awareness.

'Folk pop encourages Slovenian national awareness. It is entertaining, yet it could also be very emotional.' (CentralSlovenian region, older)

'Accordion and the fact that they [folk pop musicians] advance feelings of patriotism.' (Primorska, older)

Many interviewees also said that Slovenian folk pop is the most distinctively Slovenian music style because it depicts the beauties of Slovenia.

'Lyrics are about life in Slovenia, its countryside, nature as well as different Slovenian regions (depending on the origin of the musicians).' (Central-Slovenian region, older)

'In the songs the beauty of the motherland (Slovenia) is emphasised. Typical are also costumes (folk costumes), thythms, melodies, instruments (e. g., accordion), and (Slovenian) language.' (Štajerska, younger)

Some interviewees also claimed that Slovenian folk pop expresses something like the Slovenian national character.

'The lyrics are adapted to the Slovenians' character. They are not too optimistic; instead they are more melancholic and also said - somehow unhappy.' (Štajerska, middle-aged)

Few interviewees related Slovenian folk pop to the (traditional) cultural practices.

I don't know if they have something like this in other countries. This music [folk pop] reminds me of Sunday lunch. We used to listen to this music on radio when we had family lunch. It also reminds me of village fetes, which I used to attend with great enthusiasm.' (Central-Slovenian region, younger)

'Lyrics about the motherland, tradition, past values and about the life as we used to live it in the past.' (Pomurje, older)

In several other questions, the interviewees were also asked about their music-related memories. Even though these questions are not directly connected to the issue of national identity, there are some points that are interesting for us. Going through the answers, for example, I could not fail to notice a certain prominence of Slovenian folk pop in this respect as well. While the interviewees related their memories to diverse music styles and music-related events, when asked which kind of music they used to dislike but listen to now, the majority pointed precisely to folk pop. Here are some examples:

'At first, I did not like folk pop. But I kind of started to like it, probably because I was surrounded with it and I simply had to like it.' (Central-Slovenian region, middle-aged)

'I did not like Avseniki but I am beginning to appreciate them now' (Central-Slovenian region, middle-aged)

Notably, there are also several interviewees who stated that with time they started to like classical music.

'Classical music. I started to like it when I developed my music listening skills.' (Central-Slovenian region, middle-aged)

'I never liked classical music. But now I am beginning to like it. I am noticing that it is really complex and incredible.' (Primorska, younger) 
Yet, for the most part, it appears that it is basically Slovenian folk pop that grows to Slovenians' hearts with time. Let us now try to see what all these answers tell us about the Slovenians' understandings of the relationship between the Slovenian popular music and Slovenian national identity.

\section{Discussion}

Taken together, the answers provided by the interviewees show the almost exclusive predominance of Slovenian folk pop in Slovenians' symbolic register when thinking about the national identity in terms of music styles. I have already mentioned that the most obvious indicator of this is the sheer proportion of references to folk pop. Given that the research is not quantitative and therefore statistically not significant, this is of course not a conclusive proof, but it is not insignificant either. If one of the principles of qualitative research with interviews is that they go on until they reach the point of saturation (compare: Kvale 2007), that is, the point where the answers start to repeat themselves, we would be able to stop making them very soon as the answers with respect to the relationship between Slovenian national identity and Slovenian popular music did actually reach the point of saturation very quickly (the reason why we proceeded with the interviews is that we were not interested only in this issue). More important, the qualitative analysis of the answers provided by the interviewees points to the exactly same direction. Basically, there are two strong tendencies that could be discerned from the answers summarised in the previous chapter and that are important this respect.

The first one is related to our questions about which Slovenian popular music acts or genres could be understood as typically Slovenian and their possible defining characteristics. Here, the vast majority of interviewees not only pointed out Slovenian folk pop as virtually the only authentically Slovenian music style but also did so in a manner that suggests that this choice is for them entirely obvious. We have seen that, when asked what is typical in the selected music style and how could this be related to Slovenian national identity, they have for the most part responded with just short descriptions of Slovenian folk pop - as if this music style's Slovenianess is something entirely self-evident. Furthermore, the answers are for the most part self-referential. Many interviewees say that Slovenian folk pop is Slovenian because it is from Slovenia, because Slovenia is its content, because it is sung in Slovenian, or because it increases Slovenian national awareness. The self-referential (if not tautological) quality of the answers is that they explain a predicate with itself: Slovenian folk pop is the most Slovenian music style because it is Slovenian.

The second tendency can be identified primarily in answers to the question about which kind of music the interviewees used to dislike but listen to (or at least appreciate) now. Namely, the common denominator of most of the answers is, above all, a certain inevitability in the interviewees' music taste development: if they for the most part used to like or dislike different music styles when they were younger, they sooner or later come to appreciate Slovenian folk pop (even if they do not actively listen to this music style). What is important here is again not the sheer number of interviewees that have stated that they started to appreciate Slovenian folk pop but the discoursive framework that they employ, which is almost fatalistic. As far as the majority of answers go, one apparently does not have any alternative but to come to respect Slovenian folk pop as this is the music that everybody else likes and - even more important - as this is simply 'our' music. Another indicator in this respect is that a few decades ago, folk pop used to be equated with cultural backwardness and, as such, was almost completely rejected by the young. Nowadays, even the young seem to appreciate folk pop and several of them also listen to it. Importantly, Slovenian folk pop has also been recently 'modernised' by so-called turbo folk, a music style that combines traditional folk pop aesthetics and music conventions with more contemporary dance rhythms and references. This means that also Slovenian music scene in general sooner or later end up appreciating folk pop above all - at least when they think in terms of music and national identity.

If I sum up the points made above, I would say that two basic characteristics of the interviewees' answers are self-referentiality and inevitability. It would appear, therefore, that Slovenian folk pop functions in Slovenia as an absolutely hegemonic music signifier of Slovenianess, but what does this mean? Is this music style really so essentially Slovenian that it is impossible to think about Slovenianess outside of it? My point is that things are not that simple. 
The first thing that complicates the picture is that Slovenian folk pop, in spite of its omnipresent traditionalistic references, is actually not traditional music at all. It emerged only after World War II and is based on the music style of just one Slovenian region. More precisely, it was invented by Slavko Avsenik, who, with the support of his classically-trained musician brother Vilko, modernised the local folk music tradition by the end of the 1940s. He did so by introducing a new combination of instruments (accordion, guitar, clarinet, trumpet, and bass), a more pronounced polka rhythm, and a new way of playing the accordion (with slightly shaking it all the time) (Sivec, 2002, 282). The Avsenik Brothers' Ensemble, formed a few years later, inspired the formation of many groups that played similar music and the emergence of a distinct folk-pop music genre (Sivec, 2002: 279), but this did not happen any earlier than in the late 1950s. Furthermore, in spite of the fact that this music style is popular with Slovenians in general (we have not identified any regional differences in this respect) and that it is today apparently understood as the only truly Slovenian music genre, Slovenian folk pop is actually based on the music idiom of just one Slovenian region (Gorenjska, where the Avsenik brothers were from). In this sense, its popular appeal as the most authentic Slovenian music style is far from self-evident, which is even more obvious if we look at the distinctive costumes that the Avsenik brothers popularised: these are in fact, just like their music, of distinctively Gorenjska origin.

Another point to note in this respect is that the dominant and most distinctive instrument of Slovenian folk pop, the accordion, is itself not a traditional Slovenian music instrument at all. Slovenian folk music has been traditionally played on violins, clarinets and double-bass, while the accordion was gradually introduced to Slovenian folk music only from the mid-nineteenth century on (Sivec, 2002: 277). Interestingly, some Slovenian regions have not adopted the accordion as the most important folk instrument even today (Prekmurje, for example), but this apparently does not prevent people even from these regions to identify Slovenian folk pop as the most Slovenian music style and accordion as its most prominent instrument.

The second issue that complicates the widespread identification of Slovenian folk pop as the most typical Slovenian music among the interviewees is that its popularity in Slovenia is, in fact, itself a rather new phenomenon. I have already mentioned that until recently (that is, roughly until the early 2000s, when it witnessed something of a revival with the emergence of turbo-folk), folk pop has been predominantly understood as a culturally backward music style. This meant that both young people and urban people, for the most part, did not like it at all. It was actually often ridiculed (the derogatory term 'beef music' originates in this context), whereas a certain distancing from this music style is discernible also in our research, where middle-aged interviewees (the ones that were young a few decades ago) show rather polarised attitudes towards folk pop. While the majority accepts it as a somehow typical Slovenian music genre, there are actually many middle-aged Slovenians who actively dislike this music style. Things are different with the older and younger generations. The older generation almost uniformly like folk pop, which should not surprise us, given that folk pop was in the 1950s and 1960s, when they were growing up, almost the only music style one could listen to. Things are, however, different with the young. As I have already pointed out, the young today typically do not express the same reservations about the Slovenian folk pop as the generation of their parents (now middle-aged interviewees) does. There are still many young who do not listen to folk pop, but on the other hand there are also very few who would express their active dislike of the genre. In fact, at least according to the results of our research, there are quite some youngsters who say that they 'usually' do not listen to folk pop but do not have any problems with it one certain 'special occasions' (village fetes, parties, etc.).

So what does this significant detail say about the Slovenian folk pop? My guess would be that it proves that Slovenian folk pop has actually managed to establish itself an essentially Slovenian music style only relatively recently. It used to be very popular when it appeared in the 1950s and in the early 1960s, but that was, for the most part, because there was not much else available on the radio programmes (only few Slovenians had gramophone players at that time). Things changed in the second half of the 1960 s, when popular music from the West started to dominate the airwaves: the young massively turned to this kind of music and started to perceive Slovenian folk pop as a signifier of the Slovenian cultural conservatism, if not backwardness. This is probably not surprising, yet what we are witnessing since the early 2000 s is another change of the cultural status of Slovenian folk pop: after decades of relative unpopularity at least with the young, educated, and urban population, it apparently became a more or less unquestionable signifier of Slovenianess in general. People might not necessarily like it or listen to it, but the majority 
accept it and even appreciate it as a segment of authentic Slovenian cultural heritage. (It should be noted, however, that my thesis that Slovenian folk pop has until recently not been widely understood as 'typically' Slovenian music is difficult to prove. The reason for this is that in the previous decades there were not any systematic researches of the Slovenian tastes in music. But, if nothing else, there are the results of our own research. As we have seen, these show much greater degree of reluctance to identify with folk pop with the middle-aged generation rather than with the young).

The last detail that complicates the widespread Slovenian understanding of Slovenian folk pop as the most Slovenian music style is that there are also other music genres that contributed to the emergence of contemporary Slovenian identity, but are today apparently not recognised as such. The most notable of these are Slovenian punk and alternative music, which actively opposed communist totalitarian tendencies in the 1980s and have as such contributed significantly to the collapse of socialism and proclamation of Slovenian's independence (Lovšin et al., 2002). Given the predominantly leftist political agenda of these music scenes and the conservative inclinations of the governments that have followed the collapse of the socialist Yugoslavia, the punk and alternative musicians may nowadays have second thoughts about their activities in the 1980s. But this does not change the fact that if there is one single music style that has actually contributed to the establishment of Slovenia as an independent state, it is alternative music or punk and not Slovenian folk pop. It is, therefore, also from this point of view far from obvious that the Slovenians understand basically only folk pop as the most Slovenian music style. If nothing else, if it was not for Slovenian alternative music, Slovenia might not have existed at all as an independent political unit.

\section{Conclusion}

The results of the research have shown a widespread identification of just one music style as typically Slovenian by the Slovenian music audiences. The identification is actually so strong, that one might get the impression that Slovenian folk pop is the one and only Slovenian music style, but, as I have tried to point out above, things are not that simple. While the vast majority of Slovenians understand Slovenian folk pop as the only authentically Slovenian music style, this is far from obvious. But why do Slovenians now relate their national identity basically just to this music genre?

My guess would be that there is a combination of different factors that contribute to this. The first one is cultural re-traditionalisation of all countries that have emerged from the ashes of socialist Yugoslavia after the break-up of the federation in 1991. This argument has been developed by Carl-Ulrik Schierup (1995), who refers to the fact that, after the dissolution of socialist Yugoslavia, a country that was actively promoting both economic and social modernisation, the newly emerged states that emerged in its place turned to long suppressed conservative values of nationalism, patriotism, religion, patriarchy, and so on. Among other things, this development has contributed to the escalation of bloody conflicts between different ethnic groups in the region, but in respect to the present discussion it is more important that in this new context certain cultural fragments - usually those associated with some kind of tradition - suddenly became established as the new pillars of nation's symbolic universe.

Admittedly, certain recent contributions challenge the re-traditionalisation thesis. The point is being made that the discourses of modernization or re-traditionalisation in post-Yugoslav societies have been much more dynamic and complicated than Schierup supposes. Authors contributing to the volume edited by Daniela Koleva (2012) argue, for example, that during the period of socialism people acted in the more modern roles not because they would have internalised them but rather simply because a structure of surveillance, rewards and punishment in these societies made it prudent for them to comply. It is also significant that the discourses that they use when reflecting on their experiences during the period of socialism are far from simple. But then again, the results of my research show a significant surge of traditionalism in Slovenia, at least with respect to popular music tastes. While Slovenian folk pop used to be popular almost exclusively among the rural or more traditionally oriented population (listening to folk pop used to be a massive faux pas, at least among the younger urban generations), since the proclamation of Slovenian independence, it has gradually become accepted - and respected - across Slovenia as the only truly authentic Slovenian music style. It might be the case, however, that in Slovenia the cultural 
modernisation of the country during the period of socialism simply did not go very deep. Furthermore, perhaps the resurgence of Slovenian folk pop simply indicates the return of the not so strongly repressed traditional cultural identifications that were prevalent before the introduction of socialism.

The second reason why Slovenians relate their national identity primarily to folk pop might be the already mentioned modernisation of the genre in the early 2000s, when some new music groups (most influential were Atomik Harmonik) combined Slovenian folk pop music idioms with dance beats and sexually explicit lyrics. This development made folk pop music and iconography more acceptable to the young, who used to dislike this music style, if for no other reason than its overt traditionalism. With the advent of turbo folk, folk pop ceased to be associated with exclusively conservative values (and aesthetics), which does not mean only that it is not as problematic as it used to be for the young but also that it has even established itself as the new chic.

The third reason for the widespread Slovenian understanding of Slovenian folk pop as the most significant expression of the Slovenian national identity is also probably the most important. Here I am returning to my opening remarks about Slovenian cultural diversity. Namely, if a country culturally, historically, geographically, etc., as diverse as Slovenia wants to establish itself as a coherent entity, it probably has to organise its symbolic imaginary around simple and understandable signifiers. While this is happening already in the official discourse with public holidays, school curricula, political discourse, and so on, which all unite diverse experiences of 'Slovenianess' into a more or less coherent whole, something like a spontaneous development seems to be occurring on the level of popular music tastes as well. Here, the Slovenians identify their national identity with more or less just one music style in spite of the fact that the Slovenian popular music heritage is very rich, diverse, and related to the Slovenian national identity in most diverse manners. The reason for this identification - given that Slovenian folk pop is probably no more authentically Slovenian than any other music style played by musicians from Slovenia - cannot be, therefore, the supposed Slovenianess of folk pop as such but its ability to represent Slovenianess in the most straightforward manner. In this context it would be even possible to draw an interesting analogy with Jacques Lacan's theory about the role of the imaginary in the process of individual's identity formation. Namely, just as individual needs, according to Lacan, a stable visual identification outside of him or herself to be even able to recognise him or herself as a separate individual being, nations apparently need identification points to recognise themselves as nations in the first place (Lacan, 2002). The identifications are also somehow outside of the immediate experiences of the majority of Slovenians: if we look at Slovenian folk pop, it has actually got to do very little with the Slovenian cultural of music history - let alone the present. What it offers, however, is a stable reference point where the actual diversity of past and present experiences of Slovenianess could be brought together in a meaningful - albeit somehow anachronistic - whole.

\section{Funding}

This work was supported as part of the Popular Music Heritage, Cultural Memory and Cultural Identity (POPID) project by the HERA Joint Research Programme (www.heranet.info) which is co-funded by AHRC, AKA, DASTI, ETF, FNR, FWF, HAZU, IRCHSS, MHEST, NWO, RANNIS, RCN, VR and The European Community FP7 2007-2013, under the Socio-economic Sciences and Humanities programme. 


\section{References}

Anderson, B (1991) Imagined Communities. London: Verso Books.

Baily, J (1994) The Role of Music in the Creation of an Afghan National Identity, 1923-73. In: Stokes M (ed) Ethinicity, Identity and Music. The Musical Constructions of Place. Oxford: Berg Publishers, pp. 45-61.

Bohlman, P V (2004) The Music of European Nationalism: Cultural Identity and Modern History. Santa Barbara: ABC-CLIO, Inc.

Degirmenci K (2006) On the Pursuit of a Nation: The Construction of Folk and Folk Music in the Founding Decades of the Turkish Republic. International Review of the Aesthetics and Sociology of Music 37(1): 47-65.

Gellner E (1983) Nations and Nationalism. New York: Cornell University Press.

Koleva D (ed) (2012) Negotiating Normality: Everyday Lives in Socialist Institutions. New Brunswick: Transaction Publishers.

Kvale S (2007) Doing Interviews. The SAGE Qualitative Research Kit. London: Sage Publications.

Lacan J (2002) The Mirror Stage. In: du Gay P, Evans J and Redman P (eds) Identity: A reader. London: Sage Publications, pp. 44-50.

Lovšin P et al. (eds) (2002) Punk je bil prej: 25 let punka pod Slovenci. Ljubljana: Cankarjeva založba and ROPOT.

Schierup CU (1995) Beyond modernisation: the retraditionalisation of ex- and post-Yugoslavian society. In: Grancelli B (ed) Social Change and Modernisation: Lessons from Eastern Europe. Berlin: de Gruyter, pp. 155180.

Scrugg TM (1999) "Let's Enjoy As Nicaraguans": The Use of Music in the Construction of a Nicaraguan National Consciousness. Ethnomusicology 43 (2): pp. 297-321.

Sivec I (2002) Slovenija - zibelka narodnozabavne glasbe. In: Sivec I (ed) Tisoč najlepšib besedil. Kamnik: ICO.

Stanković P (2012) A small cinema from the other side of Alps: A historical review of Slovenian films. Film History 24(1): pp. 35-55.

Stokes M (1993) Introduction: Ethnicity, Identity and Music. In: Stokes M (ed) Ethinicity, Identity and Music. The Musical Constructions of Place. Oxford: Berg Publishers.

Sultanova R (2005) Music and Identity in Central Asia. Ethnomusicology Forum 14(2): pp. 131-142.

Štefančič, jr. M (2005) Na svoji zemlji. Zgodovina slovenskega filma. Ljubljana: UMco.

Vodopivec P (2006) Od Poblinove slovenice do samostojne dř̆ave. Slovenska zododovina od konca 18. stoletja do konca 20. stoletja. Ljubljana: Modrijan.

\section{Abstract}

\section{Rustic Obsessions: The Role of Slovenian Folk Pop in the Slovenian National Imaginary}

The article explores the relationship between Slovenian national identity and popular music. A substantial empirical research (150 interviewees form 4 different Slovenian regions) has been conducted to find out 
what kind of music Slovenians themselves perceive as typically Slovenian and what are for them the defining characteristics of this music acts or styles. The results show that the vast majority of interviewees understand as typically Slovenian just one music style, Slovenian folk pop (narodno-zabavna glasba). The key features that make Slovenian folk pop Slovenian are for them its content (beauties of Slovenia), its contribution to Slovenian national awareness, Slovenian lyrics etc. Various possible reasons for such uniform and even selfreferential answers are discussed. Among them are cultural re-traditionalisation of former Yugoslavian republics (now independent states) after the break-up of Yugoslavia in 1991, recent modernisation of Slovenian folk pop, and the need for a country culturally, historically, geographically, etc., as diverse as Slovenia to organise its symbolic imaginary around simple and understandable signifiers.

\section{Keywords}

Popular music, Slovenian folk-pop, national identity, audiences, imaginary. 